\title{
Variation in the dispersal potential of non-feeding invertebrate larvae: the desperate larva hypothesis and larval size
}

\author{
Dustin J. Marshall*, Michael J. Keough \\ Zoology Department, The University of Melbourne, Melbourne, Victoria 3010, Australia
}

\begin{abstract}
For many species of marine invertebrates, variability in larval settlement behaviour appears to be the rule rather than the exception. This variability has the potential to affect larval dispersal, because settlement behaviour will influence the length of time larvae are in the plankton. Despite the ubiquity and importance of this variability, relatively few sources of variation in larval settlement behaviour have been identified. One important factor that can affect larval settlement behaviour is the nutritional state of larvae. Non-feeding larvae often become less discriminating in their 'choice' of settlement substrate, i.e. more desperate to settle, when energetic reserves run low. We tested whether variation in larval size (and presumably in nutritional reserves) also affects the settlement behaviour of 3 species of colonial marine invertebrate larvae, the bryozoans Bugula neritina and Watersipora subtorquata and the ascidian Diplosoma listerianum. For all 3 species, larger larvae delayed settlement for longer in the absence of settlement cues, and settlement of Bugula neritina larvae was accelerated by the presence of settlement cues, independently of larval size. In the field, larger $W$. subtorquata larvae also took longer to settle than smaller larvae and were more discriminating towards settlement surfaces. These differences in settlement time are likely to result in differences in the distance that larvae disperse in the field. We suggest that species that produce nonfeeding larvae can affect the dispersal potential of their offspring by manipulating larval size and thus larval desperation.
\end{abstract}

KEY WORDS: Dispersal potential · Offspring size $\cdot$ Maternal effects

\section{INTRODUCTION}

Biologists have tended to view settling larvae as a homogenous population that reacts relatively uniformly to settlement cues (reviewed in Raimondi \& Keough 1990, Toonen \& Pawlik 2001a). Raimondi \& Keough (1990) challenged this view and highlighted the existence of substantial intraspecific variation in the settlement behaviour of most larvae that had been studied. Since then, it has been suggested that this variation may be important and adaptive, particularly as a way of dealing with variation in the adult environment (Krug 2001, Toonen \& Pawlik 2001a). Larval settlement behaviour also has the potential to affect larval dispersal strongly. Larvae that settle relatively indiscriminately are likely to settle soon after becoming competent, while those using very specific settlement cues are likely to spend longer in the plankton before encountering the appropriate cue (Toonen \& Pawlik 1994, Krug 2001). Any variation in settlement behaviour may, therefore, result in variation in the dispersal potential of larvae (Toonen \& Pawlik 1994, Krug 2001). Given that variation in the settlement behaviour of larvae within a species appears to be ubiquitous (Raimondi \& Keough 1990) and important for dispersal, it is surprising that relatively few sources of this variation have been identified. Recently, several studies have specifically addressed the causes and consequences of variation in settlement behaviour and support Raimondi \& Keough's suggestions. Krug (2001) found substantial variation in the settlement behaviour of larvae of the opisthobranch mollusc Adalaria modesta. He suggested that this variation represented a novel bet-hedging dispersal strategy, whereby some offspring recruited directly into the 
parental habitat whilst allowing dispersal of other larvae to colonise new food patches. Toonen \& Pawlik (1994) found that the larvae of the polychaete $\mathrm{Hy}$ droides dianthus also have a settlement behaviour dimorphism in which some larvae settle in response to settled conspecifics (termed 'aggregators') whilst others settle in response to unoccupied, biofilmed substratum (termed 'founders'). They further demonstrated that this settlement behaviour is heritable and argued that the behavioural dimorphism is crucial to the establishment of new populations and the maintenance of existing populations (Toonen \& Pawlik 2001a).

Another source of variation in larval settlement behaviour is variation in the 'desperation' of larvae. It has been proposed that as larvae age, they become less discriminatory (i.e. more 'desperate') in their choice of settlement substrate (Knight-Jones 1951, 1953, Wilson 1953, Gibson 1995). The desperate larva hypothesis was originally conceived from work on non-feeding barnacle and polychaete larvae (reviewed in Toonen \& Pawlik 2001b). A number of workers have suggested that the maximum planktonic period of non-feeding larvae is determined by energetic reserves (Lucas et al. 1979, Jaeckle 1994, Wendt 2000 and references therein). If larvae become less discriminatory about settlement cues as their energetic reserves decrease, then we would expect that initial variation in energetic reserves, such as might be associated with larval size, will affect the timing of any change in discrimination.

There is some evidence that larval size does influence larval longevity, with larger larvae remaining active for longer than smaller larvae in an ascidian (Marshall et al. 2002) and 3 corals (Isomura \& Nishihira 2001). However, the effect of larval size on settlement behaviour or larval desperation has rarely been addressed explicitly (see Toonen \& Pawlik 2001b). If larval size does affect larval settlement behaviour, then variation in larval size could indirectly affect the dispersal potential of the larvae of lecithotrophic marine invertebrates.

Here, we test the effects of larval size on larval swimming time for 3 species of colonial marine invertebrates, the bryozoans Bugula neritina and Watersipora subtorquata, and the ascidian Diplosoma listerianum (hereafter referred to by their genus names). These species were selected because their larvae are easy to obtain, are non-feeding and settle relatively quickly. We hypothesized that, within each species, larger larvae would have greater nutritional reserves than smaller larvae, would therefore be less desperate to settle, and consequently swim for longer than smaller larvae. In the laboratory, in the absence of any known settlement cues, we found strong effects of larval size on larval swimming in all 3 species. For Bugula we also tested whether the presence of a preferred settlement surface influenced the effect of larval size on swim- ming time in the laboratory. We hypothesised that the differences in swimming time between large and small larvae observed within each species were a result of larger larvae being 'choosier' than smaller larvae. Consequently, we predicted that in the field, larger larvae would remain in the plankton for longer and would be more discriminating towards different settlement surfaces than smaller larvae. To test these predictions, we looked at the settlement of large and small Watersipora larvae in the field on preferred and nonpreferred surfaces.

\section{MATERIALS AND METHODS}

Study animals and collection of larvae. We collected mature colonies of the ascidian Diplosoma listerianum and the encrusting bryozoan Watersipora subtorquata from artificial settlement plates at Breakwater Pier, Williamstown, Australia between December 2000 and March 2001. We collected mature specimens of another bryozoan species, Bugula neritina, from Pt. Wilson pier (January 2000) and Rosebud pier (January 2002). All locations are within Port Phillip Bay, a $2000 \mathrm{~km}^{2}$ embayment in temperate SE Australia. For all 3 species, we maintained the colonies in constant darkness for $2 \mathrm{~d}$ in aquaria with recirculating seawater $\left(\sim 15^{\circ} \mathrm{C}\right)$. We then exposed colonies to bright, fluorescent light $(2 \times 35 \mathrm{~W}$ tubes) for up to $3 \mathrm{~h}$. Diplosoma colonies began to release larvae after ca. $2 \mathrm{~h}$, Watersipora began to release larvae after ca. $1 \mathrm{~h}$ and Bugula began releasing larvae within $15 \mathrm{~min}$ of exposure to light. Larvae were collected with a pipette.

Measurement of larvae. We estimated larval size by videotaping larvae through a dissecting microscope (Olympus, $80 \times$ magnification; Panasonic CCD camera, Model: WV - CP410), selecting a video frame when the larva was in the appropriate orientation, digitising that frame, and measuring the appropriate dimensions to the nearest $5 \mu \mathrm{m}$ using an image analysis program (SigmaScan, Jandel Scientific, Ver. 1.1). For Bugula and Watersipora, we selected a frame in which the larva was oriented with the ciliated groove facing directly upwards, and measured the length of the ciliated groove and the widest point perpendicular to that groove to the nearest $\mu \mathrm{m}$. The values were then multiplied to estimate larval cross-sectional area. For Diplosoma, we measured the head length of the tadpole larvae, because pilot studies indicated that this measure was a good estimate of overall size, and was the most convenient way to measure live larvae $(r=0.87$, $\mathrm{n}=50$, Marshall unpubl. data).

Effect of larval size on settlement time in the laboratory. Larval size and settler size: Newly metamorphosed Watersipora settlers are quite flat and spread 
along settlement surfaces more than the larvae of Bugula. We were interested in estimating the size of larvae from the size of settlers, so that larval size could be estimated from field settled individuals. We measured 14 haphazardly selected larvae and allowed them to settle. We then estimated cross-sectional area of the Watersipora settlers using the technique outlined above every $6 \mathrm{~h}$ for a total of $24 \mathrm{~h}$.

Although the size of newly settled individuals was a good predictor of larval size (6 to $24 \mathrm{~h}$ after metamorphosis, see 'Results'), we were concerned that differences in the amount of time that larvae spent swimming might affect the size of the settlers (e.g. Wendt 1996, Phillips 2002, Marshall et al. 2003). To test this, we artificially delayed the metamorphosis of Watersipora larvae and determined the size of settlers. We collected 40 Watersipora larvae and we allowed half (haphazardly selected) of the larvae to settle on roughened black Perspex immediately. Each of the remaining 20 larvae was placed in its own clean, clear Perspex vial with $5 \mathrm{ml}$ of filtered $(0.45 \mu \mathrm{m})$ seawater. The vials were illuminated from above and below using bright fluorescent light for $6 \mathrm{~h}$ to prevent attachment (technique modified from Wendt 1996). The larvae were then offered a suitable settlement surface (black Perspex that had been roughened with sand paper) and all settled within approximately $10 \mathrm{~min}$. For each of the groups (delayed and not delayed), we allowed the settled larvae to develop and metamorphose for $12 \mathrm{~h}$, after which the settlers were measured.

Settlement time and larval size: We tested whether larval size affected the time larvae spent swimming prior to settlement for all 3 species. For Watersipora and Diplosoma, we haphazardly selected larvae from a pool produced by at least 5 colonies. Bugula colonies produced many more larvae than the other 2 species, so we collected larvae from 3 different colonies from Williamstown and kept them separate. We then determined whether effects of larval size on the time spent swimming varied among groups of offspring from individual maternal colonies. Larvae from a single colony are likely to be a mixture of full and half-siblings, because sperm is released into the water column, but the eggs are retained. After the measurement of larvae for each species, we placed each larva in its own vial with $5 \mathrm{ml}$ of filtered seawater. The sides of the vials were made of clear polyethylene and the base was made of grey PVC (for Watersipora and Diplosoma) or black Perspex (for Bugula). Perspex was used, because in pilot studies we found that Bugula would often settle on the water meniscus when exposed to PVC, which made reliable assessments of settlement difficult (Marshall unpubl. data). For Diplosoma and Bugula we checked for settlement every 15 min and for Watersipora we checked every $2 \mathrm{~h}$. We classed larvae as settled if they were firmly attached to the bottom or sides of the vial and could not be removed using a gentle jet of water from a pipette. We continued to check the vials until all the larvae had attached. For Diplosoma we regressed larval swimming time against larval size $(\mathrm{n}=24)$. For Watersipora we found that larvae generally settled in the first or last couple of hours; consequently, we used logistic regression rather than linear regression to examine the relationship between larval size and settlement time. All the Watersipora larvae settled within $8 \mathrm{~h}$ of release and were classed as either early or late settlers if they settled in the first or last $4 \mathrm{~h}$, respectively.

For Bugula, we used ANCOVA to test whether larval size and maternal parent affected the length of time spent swimming (after first testing for homogeneity of slopes). Larvae greater than the median $(244 \mu \mathrm{m})$ were defined as 'large' and larvae $<244 \mu \mathrm{m}$ were defined as 'small'. We then compared the coefficient of variation of swimming times between the 2 groups using a paired $t$-test, where each brood (i.e. larvae from the same maternal colony) was a replicate.

Settlement preferences: For the larvae of both Bugula and Watersipora, larval size affected the time larvae took to settle in the laboratory in the absence of any settlement cues (see 'Results; Settlement time and larval size'). Consequently we examined how the effect of larval size was mitigated by the presence of different settlement surfaces. To do this, we first determined whether Bugula and Watersipora larvae had any preference for different surface characteristics. For both species, we placed 40 larvae (of a range of sizes from 5 different colonies) in individual petri dishes (90 mm diameter). Half of each dish had been roughened with sandpaper. The dishes were partly submerged for $24 \mathrm{~h}$ in seawater aquaria so that the roughened half of the petri dish developed a biofilm whilst the other, untreated, half was completely exposed to the air. The larvae were placed in the centre of the dish with $20 \mathrm{ml}$ of filtered $(0.45 \mu \mathrm{m})$ seawater and left in the dark for $12 \mathrm{~h}$. We then noted whether larvae had settled in the treated or untreated half.

Settlement time, size and settlement surfaces: We found that the larvae of both Bugula and Watersipora strongly preferred the roughened, biofilm surfaces (see 'Results; Settlement preferences'). For Bugula, we then examined how settlement surface type influenced the effects of larval size on swimming time. We collected Bugula larvae (pooled from 10 colonies from Rosebud), measured their size as above and offered them either an untreated or roughened biofilm surface on which to settle as described above. We determined the larval swimming time for each larva as described above. We analysed the effects of larval size and settlement surface on swimming time using an ANCOVA 
where larval size was a covariate and settlement surface was a factor, after first testing for homogeneity of slopes between the 2 groups.

Effect of larval size on settlement time in the field. In the laboratory, larger larvae of all species swam longer than smaller larvae before settling (see 'Results; Settlement time and larval size'). In order to examine the effect of larval size on time until settlement in the field, 2 pieces of information are necessary - the timing of release of larvae and the size of larvae that settle. We estimated larval size from the size of settlers in Watersipora (see 'Results; Larval size and settler size'), so we used this species to examine the effects of larval size on settlement time at Breakwater Pier, where Watersipora is abundant.

We first tested whether Watersipora larvae are released in the morning, as are the larvae of other bryozoan species (e.g. Cancino et al. 1991). For the past 3 yr (2000 to 2002 inclusive), during periods of peak settlement in Watersipora, we have taken regular plankton samples throughout the day and night at Breakwater pier. In $26 \mathrm{~d}$ of sampling, the larvae of Watersipora have only been found from shortly after sunrise until 17:00 h (Marshall \& Keough unpubl. data). We further tested that larvae are only released in the morning by intensely monitoring their settlement. In January 2002 (when Watersipora were settling in high numbers), we placed 4 large $(90 \times 90 \mathrm{~cm})$ settlement plates in the field at a depth of $1.5 \mathrm{~m}$ below the mean low water mark. We then checked those plates for settlement every $4 \mathrm{~h}$ during the day and every $6 \mathrm{~h}$ during the night for $2 \mathrm{wk}$. We found that settlement only occurred between 08:00 $\mathrm{h}$ and 17:30 $\mathrm{h}$.

Timing of release in the laboratory: Given our results in the laboratory and our observations that Watersipora colonies in the field only release larvae in the morning, we expected that larvae settling in the afternoon would be larger because the smaller larvae would have settled in the morning. We assumed that larvae of all sizes are released at similar times. To test this assumption, we induced 10 mature Watersipora colonies to spawn in the laboratory, collected the first $(\mathrm{n}=25)$ and last $(\mathrm{n}=30)$ larvae released and measured their size. We found no difference in size (see 'Results; Timing of larval release in the laboratory')

In the field, we used 30 settlement plates to collect Watersipora settlers. The plates were petri dishes (90 $\mathrm{mm}$ diameter) that had an $8 \mathrm{~mm}$ hole drilled in the centre of the dish. We also interested in whether larval size affected whether larvae settled on preferred settlement surfaces or not. Half the settlement plates were pre-roughened and biofilmed (i.e. had a preferred settlement surface, see 'Results; Settlement preferences') and half were untreated. The settlement plates were attached to a large $(900 \times 900 \mathrm{~mm})$ Perspex backing plate by stainless steel bolts $1.5 \mathrm{~m}$ below the mean low water mark about halfway along Breakwater Pier at ca. 23:00 h every night, when no settlement was occurring. Approximately $5 \mathrm{~h}$ after dawn, we hoisted the backing plate out of the water and examined the settlement plates for Watersipora settlers. Any plates that had settlers on them were removed and placed in insulated aquaria with seawater for transportation to the laboratory to be measured. The plates of both types (treated and untreated) were replaced with plates that had been treated. The ages of the biofilms in all treatments were similar, but the relative time in the field or laboratory differed between treatments. This was unlikely to influence settlement patterns, as bryozoan larvae tend to react to biofilms from the laboratory and field in the same way (Keough \& Raimondi 1995). In the afternoon, approximately $6 \mathrm{~h}$ after the morning survey, we again hoisted the backing plate out of the water and collected all the settlement plates that had settlers. All the plates were then replaced with new plates (half with treated surfaces, half with untreated surfaces). We measured the size of settlers at least $6 \mathrm{~h}$ after the plates were hoisted out of the water. The settlers were at least $6 \mathrm{~h}$ old but no older than $12 \mathrm{~h}$ when they were measured, thereby ensuring that the size of the settlers when we measured them was a good predictor of larval size (see 'Results; Larval size and settler size'). The deployment of plates was repeated on 5 haphazardly selected days.

To examine the effects of larval size and surface type on settlement time in the field, we compared the size of larvae that settled in the morning and afternoon on the 2 settlement surface types. We analysed our results using a 2-way ANOVA (surface type and time of day, both fixed factors), pooling across different sampling days. Ideally, we would have included 'Day' as a random factor, but larvae did not settle on all combinations of surface type and time of settlement on every day.

\section{RESULTS}

\section{Larval size and settler size}

For Watersipora, the size of settlers $6 \mathrm{~h}$ after metamorphosis was a good predictor of the size of those individuals as larvae (Table 1). Importantly, settler size did not change from 6 to $24 \mathrm{~h}$ after metamorphosis (Table 1). Delaying the metamorphosis of Watersipora larvae did not influence the size of recently metamorphosed individuals (mean size of delayed settlers \pm $\mathrm{SE}=0.167 \pm 0.005 \mathrm{~mm}^{2} ;$ mean size of non-delayed settlers $\pm \mathrm{SE}=0.162 \pm 0.012 \mathrm{~mm}^{2} ; F_{1,39}=0.144, \mathrm{p}=$ $0.706)$. The power to detect a $20 \%$ difference in the mean size of larvae between the 2 groups was 0.79 . 
Table 1. Watersipora subtorquata. Effect of original larval size and time since metamorphosis on the size of settlers

\begin{tabular}{|lrcc|}
\hline Source & df & MS & $p$ \\
\hline Between subjects & 1 & 952.95 & $<0.001$ \\
Larval size & 12 & 24.915 & \\
Residual & & & \\
Within subjects & 3 & 0.546 & 0.420 \\
Time & 3 & 0.399 & 0.556 \\
Time $\times$ Larval size & 36 & 0.566 & \\
Residual & & \\
\hline
\end{tabular}

\section{Laboratory}

Settlement time and larval size

In the laboratory, in the absence of settlement cues, larger larvae swam for longer than smaller larvae for all 3 species (Diplosoma: $R^{2}=0.471, \mathrm{n}=24, \mathrm{p}<0.001$, Fig. 1 ; Watersipora: McFadden's $\rho^{2}=0.444, \mathrm{n}=28, \mathrm{p}=0.015$ ). This resulted in a 30-fold and an 8-fold increase in the amount of time spent swimming across the range of larval sizes for Diplosoma and Watersipora, respectively.

For Bugula, larval swimming time increased with larval size within all 3 sibships of larvae ( 8-fold between the time spent swimming by the largest and smallest larvae; ANCOVA, $F_{1,68}=3.16, p=0.032$, Fig. 2). The effect of larval size on swimming time was consistent between different sibships of larvae, although sibship did have an effect on swimming time (ANCOVA, $F_{2,68}=8.42, p=0.005 ;$ Fig. 2). It appeared that the amount of time larger larvae spent swimming prior to settlement was more variable than that of

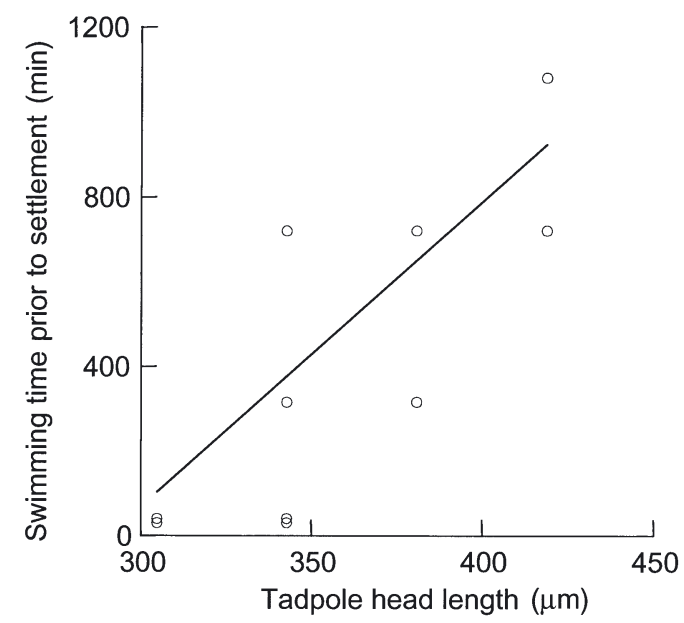

Fig. 1. Diplosoma listerianum. Effect of larval size on the time until settlement in the laboratory, in the absence of settlement cues. Each point represents a single larva, but several points overlap $(\mathrm{n}=24)$. Regression equation: Swimming time $=7.18 \times($ larval size $)-2086$ smaller larvae. However, we could not detect a difference in the coefficients of variation of swimming time between the 2 groups (mean difference \pm SD: $0.079 \pm$ 0.166 ; paired $t$-test: $t=1.28$, df $=2, \mathrm{p}=0.33$ ).

\section{Settlement preferences}

All 40 of the Watersipora larvae and 39 of the 40 Bugula larvae settled on the rough, biofilmed sides of the petri dishes.

\section{Swimming time, size and settlement surfaces}

The time that Bugula larvae spent swimming was also affected by the settlement surface. Whilst smaller larvae settled sooner than larger larvae, regardless of settlement surface, larvae of all sizes settled sooner when offered a preferred (rough) surface than when offered a non-preferred (smooth) settlement surface (ANCOVA, effect of larval size: $F_{1,41}=22.65, \mathrm{p}<0.001$, effect of settlement surface: $F_{1,41}=12.03, \mathrm{p}=0.001$; Fig. 3). Interestingly, there was no interaction between settlement surface and larval size $\left(F_{1,40}=0.017, \mathrm{p}=\right.$ 0.897).

\section{Field}

Timing of release in the laboratory

The size of larvae released by Watersipora colonies in the laboratory did not vary with the timing of their

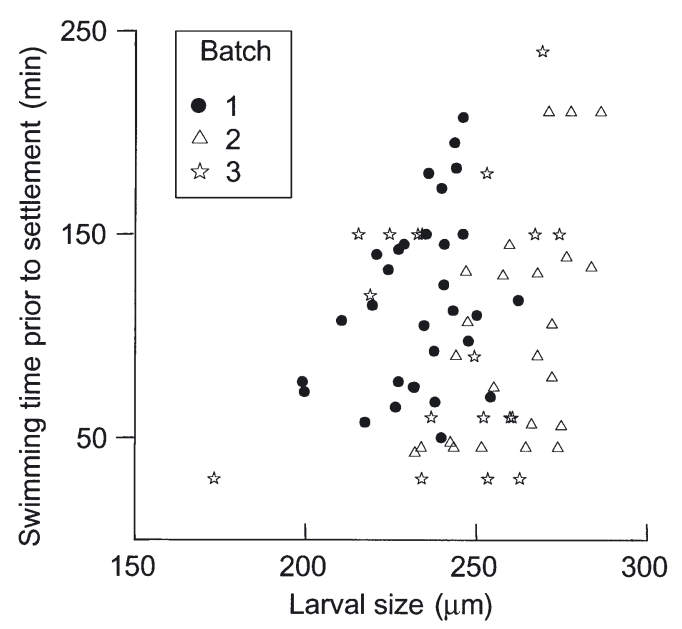

Fig. 2. Bugula neritina. Effect of larval size on the time until settlement in the laboratory, in the absence of settlement cues. Each symbol represents a different batch of larvae from a different colony, each point represents a different larva $(n=72)$ 


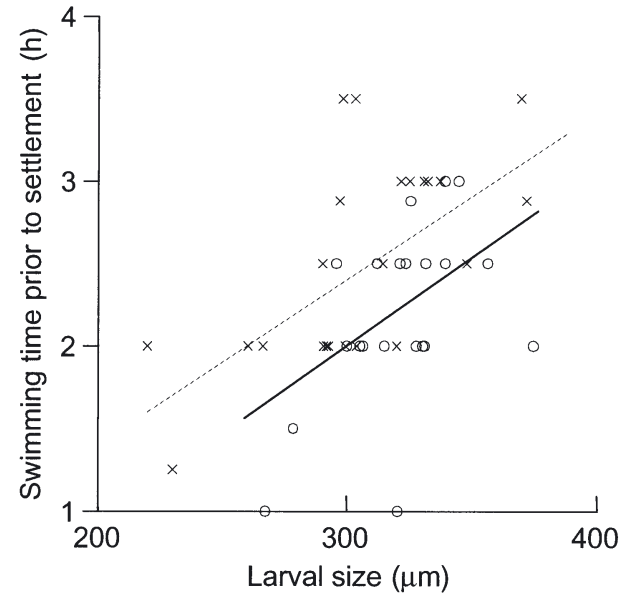

Fig. 3. Bugula neritina. Effect of larval size on the time until settlement in the laboratory, in the absence of settlement cues ( $\mathrm{n}=44) . \times, \cdots \cdot$ : larvae that were offered an untreated settlement surface; $O$, - : larvae that were offered a preroughened, biofilmed settlement surface

release (mean size of larvae released early $\pm \mathrm{SE}=0.22$ $\pm 0.01 \mathrm{~mm}^{2}$; mean size of larvae released late $\pm \mathrm{SE}=$ $0.21 \pm 0.01 \mathrm{~mm}^{2} ; F_{1,53}=0.651, \mathrm{p}=0.423$ ). The power to detect a difference of $20 \%$ between the mean sizes of larvae released early and late was 0.91 .

\section{Swimming time}

There was no difference in the number of larvae that settled in the morning and afternoon, but larvae settled in greater numbers on the rough pre-conditioned settlement plates (Table 2). The mean size of Watersipora individuals settling in the morning was much smaller than the mean size of individuals settling in the afternoon, regardless of the settlement surface (Table 3, Fig. 4). This difference appears to have occurred due to a truncation of the distribution in settler sizes in the afternoon (Fig. 4). The size of settled individuals also differed according to the surface characteristics of the settlement plates in the field. The mean size of settlers on the rough, pre-conditioned plates was greater than on the smooth, unconditioned plates at both times of day (Table 3, Fig. 4). For both the number and size of larvae that settled, there was no significant interaction between the effects of the time of day and settlement surface (Tables $2 \& 3$ ). Only 2 larvae settled on the smooth, unconditioned plates in the morning (Fig. 4). However, because there was no interaction between settlement surface and time of day (Table 3), the tests for each of these factors were effectively independent and pooled (i.e. the test of settlement surface pooled across both times of day, and the test of time of day pooled across both settlement surfaces).
Table 2. Watersipora subtorquata. Effect of settlement surface and time of day on the number of larvae settling in the field

\begin{tabular}{|lcrr|}
\hline Source & df & MS & \multicolumn{1}{c|}{$\mathrm{p}$} \\
\hline Settlement surface & 1 & 42.05 & $<0.001$ \\
Time of day & 1 & 0.45 & 0.616 \\
Time of day $\times$ & 1 & 2.45 & 0.251 \\
$\quad$ Settlement surface & & & \\
Residual & 16 & 1.725 & \\
\hline
\end{tabular}

Table 3. Watersipora subtorquata. Effect of settlement surface and time of day on the size of larvae settling in the field

\begin{tabular}{|lccc|}
\hline Source & df & MS & $\mathrm{p}$ \\
\hline Time of day & 1 & 0.022 & 0.001 \\
Settlement surface & 1 & 0.050 & 0.019 \\
Time of day $\times$ & 1 & 0.002 & 0.452 \\
$\quad$ Settlement surface & & & \\
Residual & 43 & 0.004 & \\
\hline
\end{tabular}

\section{DISCUSSION}

For each of the 3 species studied, larger larvae took longer to settle than smaller larvae in the absence of any settlement cues. For the larvae of Diploma listerianum and Watersipora subtorquata, larval size was a good predictor of the amount of time larvae spent

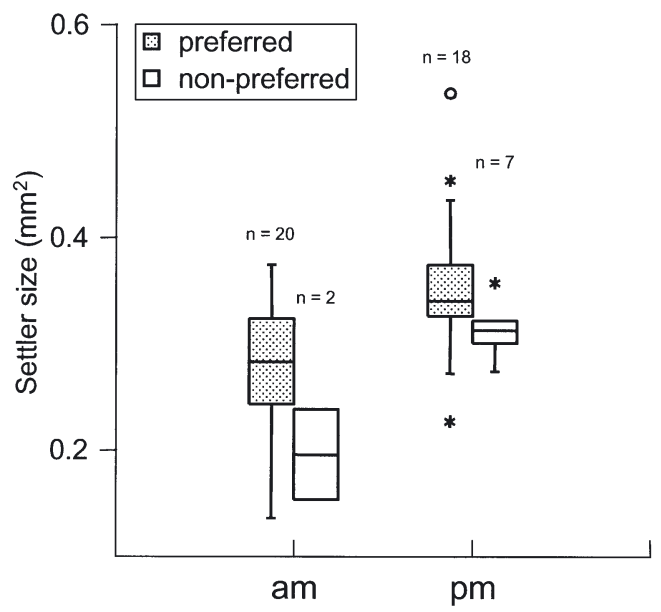

Fig. 4. Watersipora subtorquata. Size of settlers that settled on roughened (preferred) or smooth (non-preferred) settlement plates in the morning and afternoon at Williamstown Pier, Victoria, Australia. The centre horizontal bar in each boxplot represents mean, asterisks represent values within $1.5 \times$ interquartile range and open circles indicate values outside this range. The mean size of settlers during the morning on rough and smooth plates was 0.279 and $0.196 \mathrm{~mm}^{2}$, respectively. The mean size of settlers in the afternoon on rough and smooth plates was 0.356 and $0.312 \mathrm{~mm}^{2}$, respectively 
swimming prior to settlement. For Bugula neritina, the amount of time larvae spent swimming was strongly affected by larval size, but the relationship was more variable. Furthermore, there was a strong maternal effect on larval settlement time, independent of the effects of larval size in Bugula.

The amount of time that larvae were observed swimming in this study does not represent the maximum larval duration for each of these species. The larvae of each species can successfully complete metamorphosis after at least $15 \mathrm{~h}$ (Wendt 1996, Marshall et al. 2003, D. J. Marshall pers. obs). The effects of larval size on swimming time could result from 2 not mutually exclusive mechanisms. First, larger larvae could take longer to become competent to settle than smaller larvae. This is unlikely, as larvae of each species can be induced by $\mathrm{KCl}$ to metamorphose almost immediately (D. J. Marshall pers. obs., Wendt \& Woollacott 1995, Marshall et al. 2003). Furthermore, Bugula larvae of all sizes settled sooner when offered a preferred settlement surface. Therefore, the larger larvae are clearly capable of settling sooner. The second, more likely scenario is that the initial response to settlement surfaces is size-specific.

The settlement surface that was offered to the larvae of each species lacked a pre-existing biofilm and had no other cues that are known to induce settlement. Within each species, larvae of all sizes encountered what was probably a poor settlement option but smaller larvae responded and settled sooner than larger larvae. We did not test whether larger larvae have higher energetic contents than smaller larvae. For the eggs of several marine invertebrates, size is not correlated with energetic content (McEdward \& Coulter 1987, McEdward \& Chia 1991, McEdward \& Morgan 2001). Nevertheless, we believe that larger larvae of each of the species here are more likely to have higher energetic contents for several reasons. First, the results showing no relationship between egg size and energetic content are based largely on a method that has been called into question recently (Gosselin \& Qian 1998). Second, in Bugula spp. it has been shown that species with larger larvae also have greater energetic content (Wendt 2000). Third, for each species examined here, larger larvae perform better as adults than do smaller larvae (Marshall et al. in press, Marshall \& Keough unpubl. data). It appears then, that the endogenous energetic reserves of larvae are a major factor in determining the settlement behaviour of nonfeeding larvae. In terms of the desperate larvae hypothesis, smaller larvae were more desperate to settle, whereas larger larvae took longer to become desperate to settle, even though all larvae did eventually settle.

Endogenous energetic reserves were not the sole factor in the settlement behaviour of at least one of the species examined here. Bugula larvae of all sizes settled relatively sooner when offered a preferred settlement surface, but larval size still influenced the free-swimming period of larvae that were offered the preferred settlement surface. Interestingly, the effects of settlement surface and larval size were independent of each other. It is possible that the effects of larval size on swimming time could be reduced in the presence of a strong settlement inducer (as opposed to that used here), although this remains untested. Nevertheless, it appears that larval settlement behaviour is a product of both settlement cues and endogenous energetic reserves.

In the field, we found that Watersipora larvae that settled in the afternoon were larger than those that settled in the morning. This is unlikely to be due to differences in the release time of large and small larvae, as there was no relationship between the size of larvae and the time of their release in the laboratory. It is likely that larvae of all sizes were released simultaneously in the field, but smaller larvae settled out of the plankton in the morning, leaving only larger larvae to settle in the afternoon.

The difference in larval desperation between large and small larvae also translated into differences in apparent settlement preferences in the field. In the morning, smaller larvae settled in approximately equal proportions on both the preferred and non-preferred plates, whilst larger larvae settled almost exclusively on the preferred plates. In the afternoon, the remaining larvae were larger and of this subset, the largest settled on the preferred plates whilst the relatively smaller larvae settled on the non-preferred plates. If small larvae must settle as soon as possible, then they may behave more like 'dropped eggs' (Keough \& Downes 1982), settling in the first place that they contact. The importance of microrefuges for survival and growth in sessile marine invertebrates has been well established (Keough \& Downes 1982, Walters \& Wethey 1996, Maldonado \& Uriz 1998). If larger larvae are able to be more discriminating towards settlement sites than smaller larvae, then they may settle in better quality microhabitats and consequently experience greater post-metamorphic survival and growth. If true, this enhances the benefit of increased per-offspring investment in marine invertebrates. However, it is important to note that we used very simple settlement cues here (roughened, biofilmed surfaces) and further work is needed to examine how more realistic settlement cues may interact with larval condition.

There has been a growing body of evidence showing that decreases in larval energetic reserves can strongly impinge upon post-metamorphic performance (Pechenik et al. 1998, Wendt 1996, 1998, Qian \& Pechenik 1998, Marshall et al. 2003). Larval despera- 
tion in non-feeding larvae may represent a trade-off between the negative effects of delayed metamorphosis and the benefits of encountering a wider range of settlement sites, allowing settlement in the best microhabitat possible. The dispersal potential of larger larvae may be much greater than that of smaller larvae, as larger larvae can reject suboptimal settlement surfaces for longer than smaller larvae. The intraspecific differences in larval settlement behaviour and thus dispersal potential found by Toonen \& Pawlik (2001a) were principally determined by genetic factors. Over 2 very different temporal scales, Jarrett (1997) and Miron et al. (2000) found that energetic reserves strongly affect the settlement behaviour of barnacle cyprids (see also Harder et al. 2001). Larval size appears to be another source of intraspecific variation in dispersal potential in marine invertebrates. Offspring size also affects dispersal in plants, although larger seeds/fruits tend to disperse less than smaller seeds/fruits (reviewed in Parciak 2002). The differences in dispersal potential of larvae that were observed here may be a product of genotype or phenotype. Parents can manipulate offspring size in order to maximize either their own or their offspring's fitness (reviewed in Cunningham \& Russell 2000, Einum \& Fleming 2000, Marshall et al. 2002). Therefore, the potential exists for parents with non-feeding larvae to manipulate the dispersal potential of their offspring by altering larval size. If local habitats become unfavourable, then parents could increase the size of their larvae in order to maximize the chances of their offspring dispersing away. Larval size increases with colony size in Bugula neritina (Marshall et al. in press), so that larger colonies will produce more dispersive larvae that will also be more discriminating towards different settlement surfaces. It appears that the strength of links between populations in this species will depend on larval size. More generally, given that offspring size can vary greatly among populations of marine invertebrates (e.g. George 1994, Jones et al. 1996), some populations may produce much more dispersive offspring than others (i.e. some populations are more likely to act as 'source' populations than others).

Given the advantages of producing larger larvae, it is important to note that there are also some potential disadvantages. First there is the increased cost of producing larger larvae, and increases in the size of offspring are likely to result in decreases in their number (Vance 1973). Second, larger larvae that spend more time in the plankton and settle later are more vulnerable to predation and advection away from suitable habitat (Morgan 1995), although chemical defences in larvae could mitigate such effects (e.g. eastern US populations of Bugula neritina; Lindquist \& Hay 1996).
Finally, if larger larvae are choosier than smaller larvae, they may reject habitats that appear to be unsuitable, but are actually capable of supporting post-metamorphic growth, i.e. larger larvae may be too choosy (cf. larval pig-headedness, Pechenik 1999). In a temporally variable habitat, a seemingly poor initial choice may become a good one, and vice versa (Raimondi \& Keough 1990). The production of larger larvae seems riskier, but does allow for increased dispersal and/or settlement in better quality habitats. Producing larvae of a range of sizes may represent a bet-hedging strategy, whereby colonies produce some costly, risky larvae that are large, and other cheaper, smaller larvae that are less able to disperse away from the natal habitat. Alternatively, variation in larval size may simply represent a consequence of developmental constraints (reviewed in Llodra 2002) or random variability. Larval size strongly affects post-metamorphic performance in Bugula neritina, with larger larvae becoming larger adults with greater reproductive outputs (Marshall et al. in press). Clearly, the consequences of variation in larval provisioning are complex, affecting both the pre- and post-metamorphic stages of the marine invertebrate lifecycle.

Traditionally, models of optimal egg/larval size in marine invertebrates assume that an increase in peroffspring investment will shorten the planktonic period, thereby reducing planktonic mortality (Vance 1973, Podolsky \& Strathmann 1996). This is true for broad comparisons among lecithotrophs and planktotrophs. However, within some species with nonfeeding larvae, increases in egg/larval size result in an extension of the potential larval period, and increased choosiness early in the planktonic period. This result remains to be confirmed in other species of marine invertebrates.

\section{LITERATURE CITED}

Cancino JM, Hughes RN, Ramirez C (1991) Environmental cues and the phasing of larval release in the bryozoan Celleporella hyalina (L.). Proc R Soc Lond B 246:39-45

Cunningham EJA, Russell AF (2000) Egg investment is influenced by male attractiveness in the mallard. Nature 404:74-77

Einum S, Fleming IA (2000) Highly fecund mothers sacrifice offspring survival to maximise fitness. Nature 405:565-567

George SB (1994) Population differences in maternal size and offspring quality for Leptasterias epichlora (Brandt) (Echinodermata: Asteroidea). J Exp Mar Biol Ecol 175: 121-131

Gibson G (1995) Why be choosy? Temporal changes in larval sensitivity to several naturally-occurring metamorphic inducers in the opisthobranch Haminaea callidegenita. J Exp Mar Biol Ecol 194:9-24

Gosselin LA, Qian PY (1998) Analysing energy content: a new micro-assay and an assessment of the applicability of acid dichromate assay. Hydrobiologia 390:141-151 
Harder T, Thiyagarajan V, Qian PY (2001) Combined effect of cyprid age and lipid content on larval attachment and metamorphosis of Balanus amphitrite Darwin. Biofouling $17: 257-262$

Isomura N, Nishihira M (2001) Size variation of planulae and its effect on the lifetime of planulae in three pocilloporid corals. Coral Reefs 20:309-315

Jaeckle WB (1994) Rates of energy consumption and acquisition by lecithotrophic larvae of Bugula neritina (Bryozoa: Cheilostomata). Mar Biol 119:517-523

Jarrett JN (1997) Temporal variation in substrate specificity of Semibalanus balanoides (Linnaeus) cyprids. J Exp Mar Biol Ecol 211:103-114

Jones HL, Todd CD, Lambert WJ (1996) Intraspecific variation in embryonic and larval traits of the dorid nudibranch mollusc Adalaria proxima (Alder and Hancock) around the northern coasts of the British Isles. J Exp Mar Biol Ecol 202:29-47

Keough MJ, Downes BJ (1982) Recruitment of marine invertebrates: the role of active larval choices and early mortality. Oecologia 54:348-352

Keough MJ, Raimondi PT (1995) Responses of settling invertebrate larvae to bioorganic films: effects of different types of films. J Exp Mar Biol Ecol 185:235-253

Knight-Jones EW (1951) Gregariousness and some other aspects of the settling behaviour of Spirorbis. J Mar Biol Assoc UK 30:201-222

Knight-Jones EW (1953) Laboratory experiments on gregariousness during settling in Balanus balanoides and other barnacles. J Exp Biol 30:584-599

Krug PJ (2001) Bet-hedging dispersal strategy of a specialist marine herbivore: a settlement dimorphism among sibling larvae of Adalaria modesta. Mar Ecol Prog Ser 213: $177-192$

Lindquist N, Hay ME (1996) Palatability and chemical defense of marine invertebrate larvae. Ecol Monogr 66: $431-450$

Llodra ER (2002) Fecundity and life-history strategies in marine invertebrates. In: Adv Mar Biol 43:88-172

Lucas MI, Walker G, Holland DL, Crisp DJ (1979) An energybudget for the free-swimming and metamorphosing larvae of Balanus balanoides (Crustacea: cirrepedia). Mar Biol 55:221-229

Maldonado M, Uriz MJ (1998) Microrefuge exploitation by encrusting sponges: patterns of settlement and postsettlement survival. Mar Ecol Prog Ser 174:141-150

Marshall DJ, Styan CA, Keough MJ (2002) Sperm environment affects offspring quality in broadcast spawning marine invertebrates. Ecol Lett 5:173-176

Marshall DJ, Pechenik JA, Keough MJ (2003) Larval activity levels and delayed metamorphosis affect post-larval performance in the colonial ascidian Diplosoma listerianum. Mar Ecol Prog Ser 246:153-162

Marshall DJ, Bolton TF, Keough MJ (in press) Offspring size affects the post-metamorphic performance of a colonial marine invertebrate. Ecology

McEdward LR, Chia FS (1991) Size and energy content of eggs from echinoderms with pelagic lecithotrophic development. J Exp Mar Biol Ecol 147:95-102

McEdward LR, Coulter LK (1987) Egg volume and energetic content are not correlated among sibling offspring of starfish: implications for life-history theory. Evolution 41: 914-917

Editorial responsibility: Roger Hughes (Contributing Editor), Bangor, Wales, UK
McEdward LR, Morgan (2001) Interspecific relationships between egg size and the level of parental investment per offspring in echinoderms. Biol Bull 200:33-50

Miron G, Walters LJ, Tremblay R, Bourget E (2000) Physiological condition and barnacle larval behavior: a preliminary look at the relationship between TAG/DNA ratio and larval substratum exploration in Balanus amphitrite. Mar Ecol Prog Ser 198:303-310

Morgan SG (1995) Life and death in the plankton: larval mortality and adaptation. In: McEdward L (ed) Ecology of marine invertebrate larvae. CRC Press, Boca Raton, FL, p 279-322

Parciak W (2002) Environmental variation in seed number, size and dispersal of a fleshy-fruited plant. Ecology 83: 780-793

Pechenik JA (1999) On the advantages and disadvantages of larval stages in benthic marine invertebrate life cycles. Mar Ecol Prog Ser 177:269-297

Pechenik JA, Wendt DE, Jarrett JN (1998) Metamorphosis is not a new beginning. Bioscience 48:901-910

Phillips NE (2002) Effects of nutrition-mediated larval condition on juvenile performance in a marine mussel. Ecology 83:2562-2574

Podolsky RD, Strathmann RR (1996) Evolution of egg size in free spawners: consequences of the fertilization-fecundity trade-off. Am Nat 148:160-173

Qian PY, Pechenik JA (1998) Effects of larval starvation and delayed metamorphosis on juvenile survival and growth of the tube-dwelling polychaete Hydroides elegans (Haswell). J Exp Mar Biol Ecol 227:169-185

Raimondi PT, Keough MJ (1990) Behavioural variability in marine larvae. Aust J Ecol 15:427-437

Toonen RJ, Pawlik JR (1994) Foundations of gregariousness. Nature 370:511-512

Toonen RJ, Pawlik JR (2001a) Foundations of gregariousness: a dispersal polymorphism among the planktonic larvae of a marine invertebrate. Evolution 55:2439-2454

Toonen RJ, Pawlik JR (2001b) Settlement of the gregarious tube worm Hydroides dianthus (Polychaeta: Serpulidae) II: testing the desperate larvae hypothesis. Mar Ecol Prog Ser 224:115-131

Vance RR (1973) On reproductive strategies of marine invertebrates. Am Nat 107:339-352

Walters LJ, Wethey DS (1996) Settlement and early postsettlement survival of sessile marine invertebrates on topographically complex surfaces - the importance of refuge dimensions and adult morphology. Mar Ecol Prog Ser 137: 161-171

Wendt DE (1996) Effect of larval swimming duration on success of metamorphosis and size of the ancestrular lophophore in Bugula neritina (Bryozoa). Biol Bull 191: 224-233

Wendt DE (1998) Effect of larval swimming duration on growth and reproduction of Bugula neritina (Bryozoa) under field conditions. Biol Bull 195:126-135

Wendt DE (2000) Energetics of larval swimming and metamorphosis in four species of Bugula (Bryozoa). Biol Bull 198:346-356

Wendt DE, Woollacott RM (1995) Induction of larval settlement by $\mathrm{KCl}$ in three species of Bugula (Bryozoa). Invertebr Biol 114:345-351

Wilson DP (1953) The settlement of Ophelia bicornis Savigny larvae. J Mar Biol Assoc UK 32:209-233

Submitted: November 1, 2002; Accepted: April 11, 2003

Proofs received from author(s): May 28, 2003 